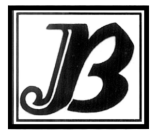

J. Bio-Sci. 29(2): 19-29, 2021 (December)

ISSN 1023-8654 http://www.banglajol.info/index.php/JBS/index

DOI: https://doi.org/10.3329/jbs.v29i2.54951

\title{
QUANTIFICATION OF HEAVY METAL ACCUMULATION IN WATER AND EDIBLE FISH TISSUE SAMPLES COLLECTED FROM THE RIVER TAWI, JAMMU, INDIA
}

\author{
M Sharma*, R Gandotra and S Jangral \\ Department of Zoology, University of Jammu, Jammu-180006, India
}

\begin{abstract}
The present study estimated the concentration (in ppm) of heavy metals of $\mathrm{Zn}, \mathrm{Fe}, \mathrm{Cu}$ and $\mathrm{Pb}$ in water samples and edible tissue of Labeo boga; both collected from the non polluted (Station I) and polluted (Station II) locations of river Tawi, Jammu, India. The mean concentration of heavy metals ( $\mathrm{Zn}, \mathrm{Fe}, \mathrm{Cu}$, $\mathrm{Pb}$ ) at Station I were 0.048 $\pm 0.008(\mathrm{ppm}) ; 0.016 \pm 0.001(\mathrm{ppm}) ; 0.157 \pm 0.002(\mathrm{ppm})$ and $0.0001 \pm 0.0001$ respectively; while at Station II, these values were $0.133 \pm 0.001(\mathrm{ppm}) ; 0.022 \pm 0.002(\mathrm{ppm})$; $0.206 \pm 0.002(\mathrm{ppm})$ and $0.002 \pm 0.001(\mathrm{ppm})$ respectively; the statistical difference between the stations were significantly higher $(p<0.05)$. The order of heavy metal load obtained in water samples at both the stations was found to be $\mathrm{Fe}>\mathrm{Zn}>\mathrm{Cu}>\mathrm{Pb}$. Also, the mean bioaccumulation of heavy metals viz. $\mathrm{Zn}, \mathrm{Fe}$, $\mathrm{Cu}$ and $\mathrm{Pb}$ in the edible tissue of fish at Station I was found to be $0.374 \pm 0.011(\mathrm{ppm}), 0.105 \pm 0.02$ (ppm); $0.094 \pm 0.04$ (ppm) and0.001 \pm 0.0001 (ppm) respectively; on the other hand, mean bioaccumulation was $0.539 \pm 0.013(\mathrm{ppm}) ; 0.156 \pm 0.04(\mathrm{ppm}) ; 0.121 \pm 0.023(\mathrm{ppm})$ and $0.0013 \pm 0.0001$ (ppm) respectively at Station II. Even though bioaccumulation of the heavy metals in the experimental sites did not exceed the acceptable limits recommended by the agencies like FAO and WHO, the present results showed an increasing trend of the accumulation, which definitely poses a serious threat to the survival of aquatic organisms in the study area.
\end{abstract}

Key words: Heavy metals, Labeo boga, Edible tissue, Bioaccumulation; Pollution

\section{Introduction}

River water forms the lifeline of all living organisms. Heavy metal pollution has become a global problem due to their environmental toxicity, persistence, bioaccumulation and biomagnification in food chain (Kumar and Seema 2016, Kumar et al. 2017, Xu et al. 2018, Ali et al. 2019). High level of heavy metals in fresh water bodies makes them unsuitable for human consumption, livestock watering and irrigation (Edokpayi et al. 2017). Heavy metals are distributed in the environment through natural processes viz. volcanic eruptions, spring water, erosion and bacterial activity; also many anthropogenic activities such as industrial effluents, sewage sludge, domestic waste, agricultural run off etc. are the prime sources of heavy metal contamination of water bodies (Zhang et al. 2014, Banaee et al. 2015, Singh et al. 2016, Farsani et al. 2019). Heavy metals can be easily converted into more toxic organic forms by microbes, some of which can be harmful to humans and aquatic organisms (Hu et al. 2013, Xu et al. 2016, Zhao et al. 2016). The heavy metal pollution may possess serious health concerns for human beings viz. renal failure, cardiovascular diseases, liver damage (IARC 2012, Rahman et al. 2012, Ying et al. 2018, Kim et al. 2019).

\footnotetext{
*Author for correspondence: monikasharma786jmd@gmail.com
} 
In recent years, consumption of fish has increased rapidly and hence awareness of its nutritional and therapeutic benefits (Bawuro et al. 2018, Kumar et al. 2020). Fish is a complete food source and highly valuable in the diet because they provide good quantity of protein and lipid of higher biological value (Gandotra et al. 2017, Rajeshkumar et al. 2018, Sumia et al. 2020). The concentration of heavy metals in fish tissue reflects the past or present exposure of fish to these contaminants (Henry et al. 2004). Edible fish present in the aquatic bodies form an important group of organisms as heavy metal accumulated in fish tissue could act as potential carrier of metal ions along the food chain. At the end, directly or indirectly, the metal ions in the aquatic medium reach to the man (Jitesh and Radhakrishnan 2017). Fish is widely used to biologically monitor the degree of metal pollution in aquatic ecosystems (Brumbaugh et al. 2005, Al-Sayegh et al. 2012, Mahurpawar 2015). As heavy metals are known for their potential toxicity and the detrimental effects on animal and human health, thus there is a growing concerns that bioaccumulation of heavy metals in fish tissue may represent a health risk (Burger and Gochfeld 2009, Ling et al. 2009, Olusola and Festus 2015).

Heavy metals like iron $(\mathrm{Fe})$, zinc $(\mathrm{Zn})$, copper $(\mathrm{Cu})$ etc are included in the group of essential trace elements required for maintaining the cellular function and are integral components of numerous metal containing enzymes (Rajkowska and Protasowicki 2013, Jia et al. 2017). These trace metals can be taken up by the fish through the food chain and from the water; and ultimately end up in the fish, where they accumulate in various organs and tissues.

The river Tawi is an important lifeline for Jammu City and its outskirts, which serves as a source of drinking water as well as a source of some local fishes to the residents of Jammu region but the river is increasingly getting polluted due to discharge of untreated sewage and dumping of municipal solid wastes, agricultural and industrial wastes and their run offs. The pollution of Tawi with heavy metals is increasing day by day which is a matter of great concern. Thus the present study was designed to quantify the level of heavy metals in the water and edible tissue samples of the fish Labeo boga, both collected from the river under study. Also such studies help in predicting pollutants transfer probability and possible health consequences to humans.

\section{Material and Methods}

\section{Study area}

Water and fish samples were collected from the two sections of the River Tawi viz., upstream section: Nagrota - latitude $32^{\circ} 46^{\prime}$, longitude $74^{\circ} 54^{\prime}$ (Station I) with non-polluted, clear and fast flowing water and downstream section: Gujjarnagar- latitude $32^{\circ} 43^{\prime}$, longitude $74^{\circ} 52^{\prime}$ (Station II) with slow-moving and polluted water due to sewage discharge, cremation wastes, religious wastes, ill-treated drainage, agricultural wastes.

\section{Assessment of heavy metals}

For heavy metal assessment, water samples were collected in polyethylene bottles (washed with $\mathrm{HNO}_{3}$ previously). Also, samples $(20 \pm 1.5 \mathrm{~cm} ; 140 \pm 1.0 \mathrm{~cm})$ of fresh water fish Labeo boga Hamilton 1882 (Cypriniformes: Cyprinidae) were collected during autumn through monsoon seasons and were dissected to obtain muscle tissues. The separated tissues were dried at $120^{\circ} \mathrm{C}$ in the petri dishes until a constant weight was obtained. The edible tissue $(1 \mathrm{mg})$ was then placed in digestion flask and ultrapure nitric acid $(8 \mathrm{ml})$ was 
added. The digestion flask was then heated at higher temperature in microwave digester until all the material was dissolved. The digest was then diluted with double distilled water and the presence of heavy metals namely, $\mathrm{Zn}, \mathrm{Fe}, \mathrm{Cu}$ and $\mathrm{Pb}$ in the samples was quantified using an atomic absorption spectrophotometer (AAS-aa 7000). Element specific cathode lamps and flame absorption mode was used to approximate the metal concentration in parts per million (ppm) both in water and tissue samples. Blank and standard solutions for the devices were used as controls.

\section{Statistical analysis}

Mean \pm SD values were estimated from the raw data. Moreover, Karl Pearson's product-moment co-efficient of correlation values $(r)$ were calculated using SPSS software to find linear relationship, if any, between the quantitative variables W (heavy metal concentrations in water) and $\mathrm{M}$ (heavy metal concentrations in fish muscles) at both selected Stations I and II.

\section{Results}

Results for the heavy metal concentration in water samples (Table 1) revealed that maximum mean concentration of heavy metals was observed during summer season, while minimum values were observed during winter season. The order of accumulation of heavy metals in water samples was observed to be $\mathrm{Fe}>\mathrm{Zn}>\mathrm{Cu}>\mathrm{Pb}$. Thus results indicated that Fe was maximally and $\mathrm{Pb}$ was least accumulated in the river. Also, results inferred higher accumulation of heavy metals in water at downstream section (Station I) as compared to upstream section (Station II).

Also in the present study, mean bioaccumulation (Fig. 1) of heavy metals ( $\mathrm{Zn}, \mathrm{Fe}, \mathrm{Cu}$ and $\mathrm{Pb}$ ) in the muscle (edible) tissue of fish at Station I was found to be $0.374 \pm 0.01(\mathrm{ppm}) ; 0.105 \pm 0.02(\mathrm{ppm}) ; 0.094 \pm 0.04$ (ppm) and $0.001 \pm 0.0001$ (ppm) respectively. Similarly at Station II (Fig. 2), mean bioaccumulation of Zn, Fe, Cu and $\mathrm{Pb}$ in edible tissue was $0.539 \pm 0.02(\mathrm{ppm}) ; 0.156 \pm 0.04(\mathrm{ppm}) ; 0.121 \pm 0.023(\mathrm{ppm})$ and $0.002 \pm 0.0001$ $(\mathrm{ppm})$ respectively. The order of accumulation of heavy metals in fish edible tissue was observed as $\mathrm{Zn}>\mathrm{Fe}>\mathrm{Cu}>\mathrm{Pb}$. Thus, zinc ( $\mathrm{Zn}$ ) was observed to be highest in fish edible tissue as compared to other heavy metals at both the stations. Similar observation has been reported by Maurya and Malik (2016), Singh and Kumar (2017) and Kumar et al. (2020). Seasonal bioaccumulation variation trend in fish edible tissue was observed to follow the order as summer>monsoon>autumn>winter. Also, increased values of heavy metal bioaccumulation were observed in edible tissue of fish at downstream section (Station II) as compared to upstream section (Station II). 
Table 1. Concentration of heavy metals ( $\mathrm{Zn}, \mathrm{Cu}$, Fe and $\mathrm{Pb}$ ) in both non polluted station (Station I) and polluted station (Station II) of river Tawi

\begin{tabular}{lcccccccc}
\hline \multirow{2}{*}{$\begin{array}{l}\text { Sampling } \\
\text { seasons }\end{array}$} & \multicolumn{9}{c}{ Heavy metal concentrations in ppm } \\
\cline { 2 - 9 } & \multicolumn{2}{c}{ Zn } & \multicolumn{2}{c}{ Fe } & \multicolumn{2}{c}{ Cu } & \multicolumn{2}{c}{ Pb } \\
\cline { 2 - 9 } & Sta. I & Sta. II & Sta. I & Sta. II & Sta. I & Sta. II & Sta. I & Sta. II \\
\hline Autumn & 0.058 & 0.079 & 0.148 & 0.216 & 0.017 & 0.026 & 0.001 & 0.003 \\
& \pm 0.013 & \pm 0.016 & \pm 0.024 & \pm 0.026 & \pm 0.002 & \pm 0.006 & \pm 0.0001 & \pm 0.0007 \\
Winter & 0.011 & 0.023 & 0.049 & 0.084 & 0.016 & 0.020 & BDL of & 0.002 \\
& \pm 0.008 & \pm 0.015 & \pm 0.020 & \pm 0.008 & \pm 0.004 & \pm 0.005 & 0.0001 & \pm 0.0006 \\
Summer & 0.081 & 0.242 & 0.265 & 0.327 & 0.024 & 0.031 & 0.001 & 0.002 \\
& \pm 0.018 & \pm 0.084 & \pm 0.132 & \pm 0.106 & \pm 0.004 & \pm 0.006 & \pm 0.0007 & \pm 0.0013 \\
& & & & & & & & \\
Monsoon & 0.042 & 0.179 & 0.173 & 0.145 & 0.007 & 0.013 & 0.001 & 0.002 \\
& \pm 0.019 & \pm 0.142 & \pm 0.192 & \pm 0.236 & \pm 0.006 & \pm 0.007 & \pm 0.0011 & \pm 0.0018 \\
\hline
\end{tabular}

Values expressed as Mean $\pm S D(n=3)$, Sta. $=$ Station.

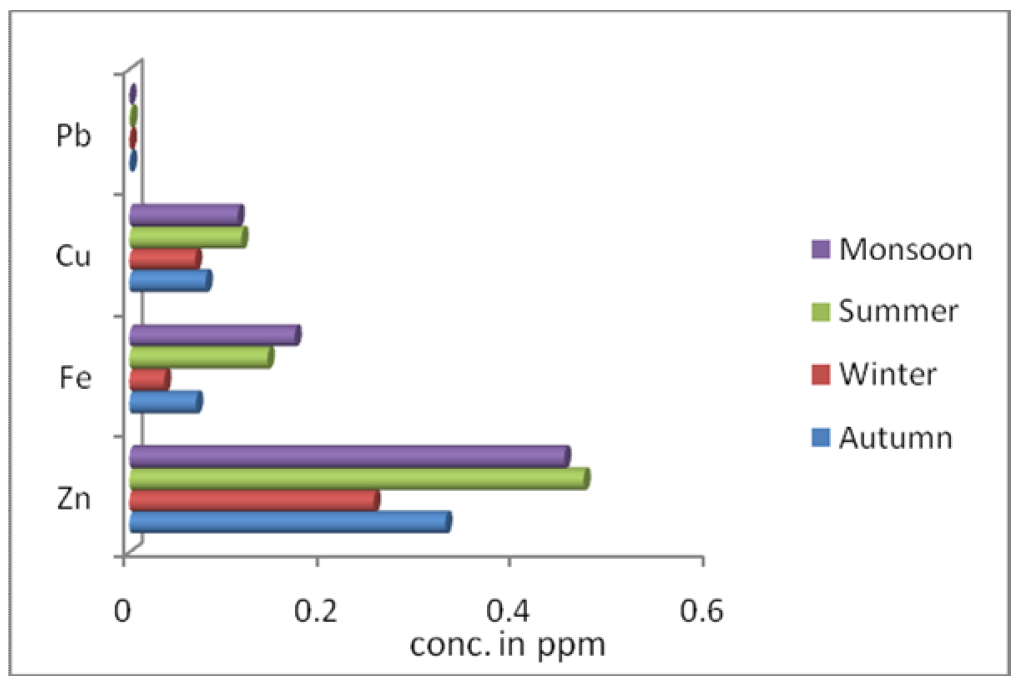

Fig. 1: Mean bioaccumulation of heavy metals $(\mathrm{Zn}, \mathrm{Fe}, \mathrm{Cu}$ and $\mathrm{Pb})$ in edible tissue of $L$. boga at Station I. 


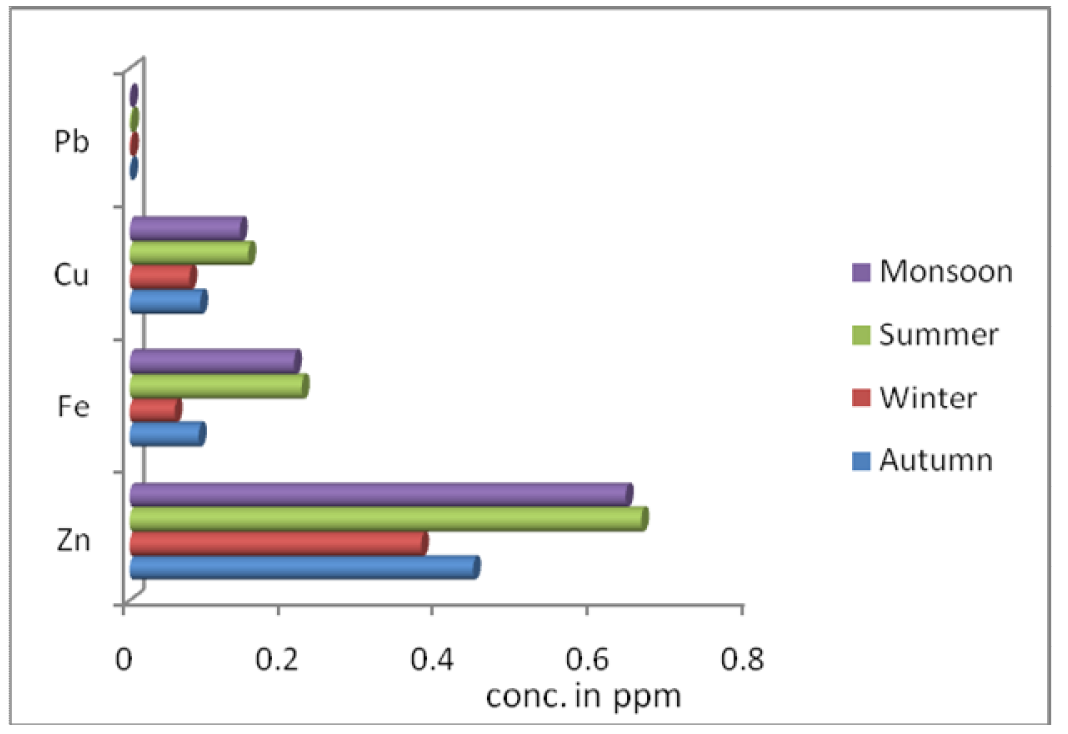

Fig. 2: Mean bioaccumulation of heavy metals ( $\mathrm{Zn}, \mathrm{Fe}, \mathrm{Cu}$ and $\mathrm{Pb}$ ) in edible tissue of $L$. boga at Station II.

Table 3. Correlation matrix for heavy metals in water samples (W) and fish edible tissue (M) at Station I

\begin{tabular}{|c|c|c|c|c|c|c|c|c|}
\hline & Zn W & Fe W & Cu W & Pb W & Zn M & Fe M & Cu M & Pb M \\
\hline Zn W & 1 & $0.940^{\star}$ & 0.528 & 0.582 & 0.741 & 0.548 & 0.674 & 0.820 \\
\hline Fe W & & 1 & 0.373 & 0.819 & 0.914 & 0.770 & 0.880 & $0.965^{\star}$ \\
\hline Cu W & & & 1 & -0.095 & 0.005 & -0.266 & -0.015 & 0.272 \\
\hline Pb W & & & & 1 & $0.973^{\star}$ & $0.973^{\star}$ & $0.992^{\star \star}$ & $0.923^{\star}$ \\
\hline Zn M & & & & & 1 & $0.961^{\star}$ & $0.992^{\star \star}$ & $0.960^{\star}$ \\
\hline Fe M & & & & & & 1 & $0.965^{\star}$ & 0.854 \\
\hline Cu M & & & & & & & 1 & $0.956^{\star}$ \\
\hline Pb M & & & & & & & & 1 \\
\hline
\end{tabular}

Co-efficient of correlation (r) values; ${ }^{*}=p<0.05$ (2-tailed); ${ }^{* *}=p<0.01$ (2-tailed). 
Table 4. Correlation matrix for heavy metals in water samples (W) and fish edible tissue (M) at Station II

\begin{tabular}{|c|c|c|c|c|c|c|c|c|}
\hline & Zn W & Fe W & Cu W & Pb W & Zn M & Fe M & Cu M & Pb M \\
\hline Zn W & 1 & 0.753 & 0.265 & 0.304 & $0.949^{\star}$ & 0.912 & $0.927^{\star}$ & 0.260 \\
\hline Fe W & & 1 & 0.801 & 0.714 & 0.528 & 0.436 & 0.467 & 0.331 \\
\hline Cu W & & & 1 & 0.572 & -0.048 & -0.151 & -0.114 & 0.543 \\
\hline Pb W & & & & 1 & 0.156 & 0.082 & 0.095 & -0.337 \\
\hline Zn M & & & & & 1 & $0.994^{\star \star}$ & $0.997^{\star \star}$ & 0.066 \\
\hline Fe M & & & & & & 1 & $0.999^{\star \star}$ & 0.023 \\
\hline $\mathrm{Cu} \mathrm{M}$ & & & & & & & 1 & 0.054 \\
\hline $\mathrm{Pb} \mathrm{M}$ & & & & & & & & 1 \\
\hline
\end{tabular}

Co-efficient of correlation $(r)$ values; ${ }^{*}=p<0.05$ (2-tailed); ${ }^{* \star}=p<0.01$ (2-tailed).

Pearson correlation matrix shown in Table 3 and 4 depicts relationship between heavy metals in water and heavy metals in fish edible tissue. At upstream section (Station I), iron $(\mathrm{Fe})$ in water showed positive correlation with lead $(\mathrm{Pb})$ in muscle $(r=0.965 ; p<0.01)$; zinc $(\mathrm{Zn})$ in muscle showed strong positive correlation with copper $(\mathrm{Cu})$ in muscle $(r=0.992 ; p<0.05)$. Also at downstream section (Station II), zinc $(\mathrm{Zn})$ in water showed positive correlation with copper $(\mathrm{Cu})$ in muscle $(r=0.927 ; p<0.01)$; zinc $(\mathrm{Zn})$ in muscle showed strong positive correlation with iron $(\mathrm{Fe})$ in muscle $(r=0.994 ; p<0.05)$ and with copper in muscle $(r=0.997 ; p<0.05)$.

\section{Discussion}

In the present study, the highest concentration of heavy metals in water samples observed in summer season followed by post monsoon. Such increase in conc. of heavy metals during the summer season could be due to increased leaching movement of heavy metals from the sediments to the surface water under the effect of high temperature; also due to fluctuations in the amount of sewage and domestic discharge into the water body. Similar types of results reported by Ellahi and Hossain (2011), Zhao et al. (2016), Jitesh and Radhakrishnan (2017) and Bhuyan and Bakar (2017). Also, the elevated level of heavy metals in water at downstream section could be due to increased downward flow of water (Karabassi et al. 2008); also due to increased waste discharge from various sources along the stretch of Station II. Similar trend of variation in heavy metal concentration at downstream and upstream stations of river has been reported by Andotra (2014) and Kumar et al. (2020). Iron and zinc were found to be present in high levels in water samples (in present study) as compared to the copper and lead. Zinc is discharged in rivers in the form of effluents from electroplating industries, sewage discharge, immersion of painted idols. Zinc toxicity causes vomiting, diahrrhoea, liver and kidney damage (Boxall et al. 2000, Gautam et al. 2015). Iron comes into water from natural geological sources, industrial waste, domestic discharge etc. Excess of Iron may cause coagulation in blood vessels, drowsiness, hypertension. Lead is present in paints, storage batteries, glass etc. Higher levels of lead leads to cognitive impairment in children, development delays (Kaur 2012, Malik et al. 2014). 
Copper sources into water body may include copper smelting, ore processing activities, windblown dust etc and it usually causes headache, nausea, vomiting, diarrhea, kidney damage etc (Gautam et al. 2015). Similar, studies on the determination of heavy metal load in river water so as to assess water quality has been conducted by several researchers (Gulfraz et al. 2001, Paliwal et al. 2007, Malik et al. 2014, Mohamed et al. 2014, Ahmed et al. 2015, Singh et al. 2019, Mishra et al. 2020).

Fish serves as standard organism to determine the bioaccumulation and impact of heavy metal pollution. The bioaccumulation of heavy metals in different fish tissues has been estimated by several investigators (Mohamed 2000, Subartha and Karuppasamy 2008, Javed and Usmani 2011, Malik et al. 2014, Shaikh 2014, Noor and Zutshi 2016, Jia et al. 2017, Mubarakh and Ali 2020). At station II, increased bioaccumulation of heavy metals in edible tissue could be due to higher level of heavy metals in surrounding water as compared to Station I and hence resulted into more absorption/ accumulation in fish body. It is mostly assumed that metals are taken up in ionic form and are influenced by various environmental factors such as pH and temperature (Ibrahim and Omar 2013). The metal contamination in river water can be absorbed into algae and aquatic plants via roots resulting in their accumulation mainly in stem and leaves and finally metals can be accumulated in herbivore fish including Labeo boga after being fed (Soulivongsa et al. 2020). Also, during the present study, increased bioaccumulation of heavy metals in fish tissue has been reported during summer season. Increase in temperature also increases the toxicity as due to depletion of dissolved oxygen, energy demand increases causing rise in the respiration rate in organism, which leads to rapid assimilation of wastes (Salem et al. 2014). Also, increased water temperature in summer increases the metabolic rate and feeding activity of fish, resulting in an increase in metal uptake and accumulation in tissues, inturn leading to higher values for the heavy metal (Obasohan 2008). Such trend of seasonal variation in tissue bioaccumulation of heavy metals has been supported by findings of Khaled (2004), Bahnasawy et al. (2009) Bahnasawy and Khidr (2011) and Ibrahim and Omar (2013).

To assess the public health risk of consuming fish from river Tawi, metal concentrations in water samples and fish edible tissue were compared with Maximum Permissible Limits (MPL) for human consumption as set by various organizations (USEPA 1976, FAO 1983, WHO 2008/2011). Results suggested the heavy metal concentrations in water samples and edible tissue of fish were found to be satisfactorily lower than standard limits, except for iron $(\mathrm{Fe})$ concentration in water samples which was found to be high as per standards proposed by USEPA 1976 (0.3 ppm for Fe).

\section{Conclusion}

The main motive behind conducting the present study was to quantify the toxicity levels of some common heavy metals in water and fish tissues and hence to determine the suitability of water and fishes for human consumption. The results revealed that consuming fishes from the River Tawi may not be harmful to consumers because the observed concentrations of the heavy metals were much below the permissible limits recommended by FAO/WHO. However, trace metallic loads in the water bodies should be continuously monitored as their rising levels might cause potential damage to the aquatic organisms and human health in the near future.

\section{Conflict of interest}

The authors hereby declare no conflict of interest regarding the publication of this article. 


\section{References}

Ahmed MK, Baki MA, Islam MS, Kundru GK, Sarkar SK and Hossain MM (2015). Human health risk assessment of heavy metals in tropical fish and shell fish collected from the river Buriganga, Bangladesh. Environmental Science and Pollution Research, 4: 236-244.

Ali $\mathrm{H}$, Khan E and Ilahi I (2019). Environmental Chemistry and Ecotoxicology of hazardous heavy metals: environmental persistence, toxicity and bioaccumulation. Journal of Chemistry: 1-14.

Al-Sayegh PS, Mazej GZ and Pokorny B (2012). Heavy metals and arsenic concentrations in ten fish species from the Salek lakes (Slovenia): assessment of potential human health risk due to fish consumption. Environmental Monitoring and Assessment, 184: 2647-2662.

Andotra P (2014). Impact of pollution on the water quality and fishes of River Tawi. PhD thesis. Department of Zoology, University of Jammu. Jammu.

Bahnasawy M and Khidr AN (2011). Assessment of heavy metals in water, plankton and fish of Lake, Manzala, Egypt. Turkish Journal of Zoology, 35(2): 271-280.

Bahnasawy M, Khidr A and Dheina N (2009). Seasonal variations of heavy metal concentrations in Mullet, Mugil cephalus and Liza ramada (Mugilidae) from Lake Manzala, Egypt. Egyptian Journal of Applied Science and Research, 5(7): 845-852.

Banaee M, Mohammadipour S and Madhani S (2015). Effects of sublethal concentrations of permethrin on bioaccumulation of cadmium in zebra cichlid (Cichlasoma nigrofasciatum). Toxicological and Environmental Chemistry, 97(2): 200-207.

Bawuro AA, Voegborlo RB and Adimado AA (2018). Bioaccumulation of heavy metals in some tissues of fish in Lake Geriyo, Adamawa State, Nigeria. Journal of Environmental and Public Health, pp. 1-7.

Bhuyan MS and Bakar MA (2017). Seasonal variations of heavy metals in water and sediments in the Halda River, Chittagong, Bangladesh. Book Eds: Environmental Science and Pollution Research, pp. 227-242.

Boxall ABA, Comer SD, Conrad AU, Howcroft J and Zaman N (2000). Inputs, monitoring and fate modelings of antifouling biocides in U K estuaries. Marine Pollution Bulletin, 40: 898-905.

Brumbaugh WG, Schmitt CJ and May TW (2005). Concentrations of cadmium, lead, and zinc in fish from mininginfluenced waters of Northeastern Oklahoma: sampling of blood, carcass, and liver for aquatic biomonitoring. Arch. Environ. Contam. Toxicol., 49: 76-88.

Burger J and Gochfeld M (2009). Perceptions of the risk and benefits of fish consumption: Individuals choices to reduce risk and increase health benefits. Environmental Research, 109: 343-349.

Edokpayi JN, Odiyo JO, Popoola EO and Msagati TAM (2017). Evaluation of temporary seasonal variation of heavy metals and their potential ecological risk in Nzhelele River, South Africa. Open Chemistry, 15: 272-282.

Ellahi MMA and Hossain AMI (2011). Assessment of spatial and temporal variations of water quality in the coastal areas of Bangladesh. BSc Engg. Thesis. Department of Civil Engineering, Khulna University of Engineering and Technology, Bangladesh.

Farsani NM, Haghparast JR, Naserabad SS, Moghadas F, Bagheri T and Gerami H (2019). Seasonal heavy metals monitoring of water, sediment and common carp (Cyprinus carpio) in Aras Dam Lake of Iran. International Journal of Aquatic Biology, 7(3): 123-13.

Food and Agriculture Organization (1983). Compilation of legal limits for hazardous substances in fish and fishery production, FAO Fishery Circular, 464: 5-100.

Gandotra R, Sharma M, Sharma S and Kumari K (2017). Studies on the variations in the proximate composition of Labeo boga in relation to habitat and season. International Journal of Recent Scientific Research, 8(6): 17544-17549. 
Goutam Rk, Sharma SK, Mahiya S and Chattopadhyaya MC (2015). Contamination of heavy metals in Aquatic media: Transport, Toxicity and Technology for remediation. In: Heavy metals in water: Presence, Removal and Safety. The Royal Society of Chemistry.

Gulfraz M, Arhad M and Ahmed T (2001). Determination of selected trace metals in the fish and relevant water of river Soan (Pakistan). Pakistan Journal of Agricultural Sciences, 4(1-2): 105-159.

Henry F, Amara R, Courcot L, Lacouture D and Bertho ML (2004). Heavy metals in four fish species from the French coast of the eastern English Channel and southern side of North seas. Environmental International, 30: 675-683.

Hu B, Cui R, Li J, Wei H, Zhao J and Bai F (2013). Occurrence and distribution of heavy metals in surface sediments of the Changhua River Estuary and adjacent shelf (Hainan Island). Marine Pollution Bulletin,76: 400-405.

IARC (2012). IARC monographs on the evaluation of carcinogenic risks to humans. Arsenic, metals, fibers and dusts. A review of human carcinogens, 100C. IARC Monogr Eval Carcinog Risks Hum. 100: 11-465.

Ibrahim ATA and Omar HM (2013). Seasonal variation of heavy metal accumulation in muscles of African catfish Clarias gariepinus, River Nile water and sediments at Assiut Governorate, Egypt. Journal of Biological and Earth Sciences, 3(2): 236-248.

Javed $M$ and Usmani $N$ (2011). Accumulation of heavy metals in fishes: A human health concern. International Journal of Environmental Sciences, 2(2): 659-668.

Jia $Y$, Wang $L$ and Du $Z$ (2017). Effects on heavy metals accumulation in fresh water fishes: species, tissues and sizes. Environmental Science and Pollution Research, 24: 9379-9386.

Jitesh M and Radhakrishnan MV (2017). Seasonal variation in accumulation of metals in selected tissue of Ribbon fish, Trichiurus lepturus, collected from the Chaliyar river, kerala, India. Journal of Entomology and Zoology Studies, 5(1): 51-56.

Karbassi AR, Monavari SM, Nadi BRG, Nouri J and Nematpour K (2008). Metal pollution assessment of sediment and water in the Shur River. Environmental Monitoring and Assessment, 147: 107-117.

Kaur S (2012). Assessment of heavy metals in summer \& winter seasons in river Yamuna segment flowing through Delhi, India. Journal of Environment and Ecology, 3(1): 149-165.

Khaled A (2004). Heavy metal concentration in certain tissues of five commercially important fishes from El-Max bay, Alaxandria, Egypt. Egyptian Journal of Aquatic Biology and Fisheries, 8(1): 51-64.

Kim JJ, Kim YS and Kumar V (2019). Heavy metal toxicity: An update of chelating therapeutic strategies. Journal of Trace Elements in Medicine and Biology, 54: 226-231.

Kumar A and Seema (2016). Accumulation of heavy metals in soil and green leafy vegetables, irrigated with wastewater. IOSR Journal of Environmental Science, Toxicology and Food Technology, 10(7): 8-19.

Kumar A, Kumar A and Jha SK (2020). Distribution and bioaccumulation of heavy metals in water, sediment and fish tissue from the river Mahananda, North Bihar, India. International Journal of Aquatic Biology, 8(2): 109-125.

Kumar A, Seema and Kumar V (2017). Human health risk of heavy metals in vegetables grown in contaminated soil irrigated with sewage water. American Journal of Food Science and Nutrition, 4(4): 23-35.

Ling MP, Hou HT, Shie RH, Wu CC and Hong YS (2009). Health risks of consuming heavy metals in farmed Tilapia in central Taiwan. Bulletin of Environmental Contamination and Toxicology, 61: 461-471.

Mahurpawar M (2015). Effects of heavy metals on human health. [Social issues and Environmental Problems]. September 2015.

Malik D, Singh S, Thakur J Singh R K, Kaur A and Nijhawan S (2014). Heavy metal pollution of Yamuna River: An Introspection. International Journal of Current Microbiology and Applied Sciences, 3(10): 856-863. 
Maurya PK and Malik DS (2018). Bioaccumulation of heavy metals in tissues os selected fish species from the Ganga River, India and risk assessment of human health. Human and Ecological Risk Assessment: An International Journal, pp. 245-253.

Mishra S, Kumar A and Shukla P (2020). Estimation of heavy metal contamination in the Hindon River, India: An Environmentric approach. Applied Water Science, 11(2).

Mohamed EG, Ali MH, Ibrahim A, Abdel-Moniem, Ayman HF and Saliem M (2014). Evaluation of surface water quality and heavy metal indices of Islamia canal, Nile River, Egypt. Egyptian Journal of Aquatic Research, 40: 225-233.

Mohammed FAS (2000). Toxicity and bioaccumulation of $\mathrm{Cu}, \mathrm{Zn}$ and $\mathrm{Cd}$ in some aquatic organisms. Bulletin of Environmental Contamination and Toxicology, 64(5): 740-747.

Mubarakh AT and Ali AM (2020). Determination of some heavy metal content in the body of two popular fish species, $O$. niloticus and L. niloticus, in lake Nubia, wadi Halfa, Sudan. Journal of Aquaculture and Marine Biology, 9(5): 170175.

Noor M and Zutshi B (2016). Bioaccumulation of trace metals in tissues of Rohu fish for Environmental Risk Assessment. Journal of Water Resource and Protection, 8: 472-481.

Obasohan EE (2008). Heavy metal concentration in the gill, muscle and liver of fresh water mud fish (Parachanna obscura) from Ogha River, Benin city, Nigeria. African Journal of Biotechnology 6: 2620-2627.

Olusola JO and Festus AA (2015). Assessment of heavy metals in some marine fish species relevant to their concentration in water and sediment from coastal waters of Ondo state, Nigeria. Journal of Marine Science: Research and Development, 5(2): 5:163. doi:10.4172/2155-9910.1000163.

Paliwal R, Sharma P and Kansal A (2007). Water quality modeling of the river Yamuna (India) using QUAL2EUNCAS. Journal of Environmental Management, 83(2): 131-44.

Rahman MS, Molla RH, Saha N and Rahman A (2012). Study on heavy metals levels and its risk assessment in some edible fishes from Bangshi River, Savar, Dhaka, Bangladesh. Food Chemistry, 134(4): 1847-1854.

Rajeshkumar S, Liu Y, Zhang X, Ravikumar B, Bai G and Li X (2018). Studies on seasonal pollution of heavy metals in water, sediment, fish and oyster from the Meiliang Bay of Taihu Lake in China. Chemosphere, 191: 626-638.

Rajkowska M and Protasowicki M (2013). Distribution of metals (Fe, Zn, Cu and Pb) in fish tissues in two lakes of different trophy in Northwestern Poland. Environmental Monitoring and Assessment, 185: 3493-3502.

Salem ZB, Capelli N, Laffrey X and Elise G (2014). Seasonal variation of heavy metals in water, sediments and roach tissues in a landfill draining system pond. Ecological Engineering, 69: 25-37.

Shaikh M (2014). Bioaccumulation of heavy metals in tissues of Labeo rohita from nathsagar dam, near Aurangabad Maharshtra. International Journal of advances in Agricultural and Environmental Engineering, 1(1): 53-55.

Singh SK, Purful S and Gautam SK (2016). Appraisal of urban lake water quality through numerical index, multivariate statistics and earth observation data sets. International Journal of Environmental Science and Technology, 13: 445456.

Singh UK and Kumar B (2017). Pathways of heavy metal contamination and associated human health risk in Ajay River basin, India. Chemosphere, 174: 183-199.

Singh V, Sharma MP, Sharma S and Mishra S (2019). Bioassessment of River Ujh using benthic macro invertebrates as bioindicators, India. International Journal of River Basin Management, 17: 79-87.

Soulivongsa L, Tengjasoenkal B and Neeratanaphan (2020). Effects of contamination of heavy metals and metalloids on chromosome, biochemistry and histopathology of the bonylip Barb fish near sepon Gold copper mine, Lao PDR. International Journal of Environmental Research and Public Health, 17: 9492. 
Subathra S and Karuppasamy R (2008). Bioaccumulation and depuration pattern of copper in different tissues of Mystus vittatus, related to various size groups. Archives of Environmental Contamination and Toxicology, 54: 236-244.

Sumia A, Namir NO, Osman O and Mujawah AA (2020). Determination of some heavy metals in sediment samples collected from Elabedia Traditional Gold mining areas-Sudan. American Journal of Pharm. Research, 10(2): 135144.

United State Environmental Protection Agency (1976). Quality criteria for water, USEPA, Washington DC 440: 76-123.

WHO (2008). Guidelines for drinking water quality, World Health Organization. Geneva, Switzerland.

WHO (2011). Guidelines for Drinking Water Quality, 4th Edition, World Health Organization. Geneva, Switzerland.

Xu J, Chen Y, Zheng L, Liu B, Liu J and Wang X (2018). Assessment of heavy metal pollution in the sediment of the main tributaries of Dongting lake, China. Water, 1(1060): 1-16.

Xu J, Wang H, Liu Y, Ma M, Zhang T and Zheng X (2016). Ecological risk assessment of heavy metals in soils surrounding oil waste disposal areas. Environmental Monitoring and Assessment, 188(125), https://doi.org/10.1007/s10661-016-5093-X.

Ying XL, Gao ZY, Yan J, Zhang M, Wang J and Xu J (2018). Sources, symptoms and characteristics of childhood lead poisoning: Experience from lead specialty clinic in China. Clinical Toxicology, 56(6): 397-403

Zhang C, Yu ZG, Zeng GM, Jiang M, Yang ZZ, Cui F, Zhu MY, Shen LQ and Hu L (2014). Effects of sediment geochemical properties on heavy metal bioavailability. Environment International, 73: 270-281.

Zhao G, Ye S, Yuan H, Ding X and Wang J (2016). Distribution and contamination of heavy metals in surface sediments of the Daya Bay and adjacent shelf, China. Marine Pollution Bulletin, 112: 420-426.

(Manuscript received on 14 March 2021; revised on 02 May 2021) 